\title{
Research on Managerial Self-interest and Corporate Donation
}

\author{
Furong Guo ${ }^{1}$ \\ Business School, Sichuan University, \\ Chengdu, China
}

\begin{abstract}
Corporate donation is not only influenced by the enterprise, but also driven by the managerial self-interest. Based on the data of Listed Companies in China from 2008 to 2017, this paper empirically examines the influence of managerial selfinterest and actual controllers on corporate donations. The results show that the greater the power of management, the more corporate donations, while the existence of actual controllers can restrain the self-interest behavior of management, and alleviate the impact of agency costs on corporate donations.
\end{abstract}

Keywords-managerial self-interest; corporate donation; the management; actual controller

\section{INTRODUCTION}

The donation in 2008 Wenchuan Earthquake started the wave of enterprise donation in China. The motivation of enterprise donation includes strategic motivation, political motivation, management utility motivation and altruistic motivation [1]. Strategic donation, as one of the motives of corporate donation, breaks the traditional assumption of corporate social responsibility (CSR) that corporate economic goals and social goals go from one to the other. Even in the case of performance decline and loss, enterprises also have such motives of donation behavior [2-3]. The political motivation of enterprises is more widespread. Some enterprises are engaged in "political donation" for the purpose of obtaining political relations, while others are in order to obtain government subsidies [4-5]. Donation can not only play an "advertising effect", but also enhance the ability of enterprises to obtain loyal customers and employees, transmit the signal of future development prospects of enterprises, and enhance the value-added of enterprises [3, 6-8].

Since corporate donation is so important to the development of enterprises, the decision-making motivation of managers as decision makers and executives is worth exploring According to agency theory, the goals of managers and shareholders are not always the same. The self-interest behavior of managers is reflected in a way of maximizing their own interests by sacrificing the shareholders' interest [9]. The managers of enterprises use donations to enhance their personal reputation and promote their own career development, resulting in agency problems. Based on this, this paper explores the interaction between managerial power and actual controllers, and empirically tests the influence of managerial self-interest and actual controllers on corporate donations. The contributions of this paper are as follows: Firstly, we analyze the evidence of the influence of management self-interest on corporate donation, which enriches the influence of agency theory on corporate donation. Secondly, we study the

\author{
Shengdao $\mathrm{Gan}^{2}$ \\ Business School, Sichuan University, \\ Chengdu, China
}

interaction between managers and actual controllers, and further reveal the role of actual controllers in social donation.

\section{THEORY AND HYPOTHESES}

\section{A. Managerial Self-interest and Corporate donations}

According to agency theory, the goals of managers and shareholders are not always the same. Managers have the selfinterest behavior of maximizing their own interests by sacrificing the interests of shareholders. As power increases, managers have more freedom in decision-making and thus it's more possible for them to seek rent through power. Donation, which is regarded as the highest form of CSR and one of the core contents of corporate, is not only legitimate and in line with public values, but also gains political and social status for managers as well as establishing a good image and reputation of social responsibility for the corporate [10-12]. As a result, managers often choose to realize their personal interests through corporate donations [8,15-16].

Based on the above, we propose hypothesis 1:

Hypothesis 1: Managerial self-interest promotes corporate donation.

\section{B. Actual Controller and Corporate donations}

According to the ultimate control theory, the controlling shareholders have significant control over the operation of the company. They have the motivation to supervise the managers and solve the agency problem between themselves and the managers [9]. As a voluntary social responsibility behavior of enterprises, corporate donation has no external control and can be chosen by enterprises. However, the proportion of the largest shareholder in a company without actual controller is often less than $35 \%$. Shareholders' supervision of management is weak, and there is a "free rider" behavior among shareholders, leading to power of the company often in the hands of managers.

Based on the above, we propose hypothesis 2:

Hypothesis 2: Compared with enterprises without actual controllers, enterprises with actual controllers inhibit the influence of self-interest behavior of management on corporate donations. 


\section{METHODS AND VARIABLES}

\section{A. Data Collection}

Since the Wenchuan earthquake in 2008, Chinese enterprises have set off a wave of charitable donations, so the time window for our study is 2008-2017. The amount of corporate donations in this paper comes from the column of "non-operating expenditure" in the notes to the financial statements of listed companies, including "donation expenditure", "public welfare donation expenditure", "nonpublic welfare donation expenditure" and "external donation expenditure". The data of GDP per capita in 2017 are from the National Bureau of Statistics, and the market is from Fan Gang's total score of the market process in 2009. The rest of the data are from the CSMAR database. We screened the samples as follows: (1) Excluding the listed companies in the financial industry and ST,* ST samples. (2) Excluding the observation of missing values of each control variable in the model. (3) To avoid the influence of extreme value, we processed the continuous variables with winsorizing at the upper and lower 1\% level, and finally got 14867 sample observations of 3439 listed companies.

\section{B. Measurement of Variables}

Dependent Variables: Donation

Referring to the existing literature [17], we adopt the following methods to measure corporate donation behavior: the proportion of total corporate donation to business income, which can eliminate the scale effect of enterprises

Independent Variables: Power

Referring to Jun [18] using management power to measure managerial self-interest, this paper also regards management power as an alternative variable of management self-interest. The power of management consists of two parts: one is the acquisition and strengthening of power, which comes from the distribution of power between managers and directors; the other is the restriction and supervision of power, which mainly comes from the supervision and balance of shareholders. Based on this, this paper measures management power from two aspects: control structure and ownership structure. Among them, the structure of control right reflects the position power of spatial dimension, and the core managers' concurrent positions as directors and even chairmen will strengthen their actual control over enterprises; the structure of ownership reflects the checks and balances of ownership distribution on the power of management, the higher the degree of ownership concentration, the smaller the power of management.

- Control Variables

According to previous studies [6-7,18], this paper sets the following control variables in the model: the logarithm of top three executive compensation (Msalary), cash ratio (Cashrate), independent director ratio (Indep), marketization process (Market), growth, per capita GDP logarithm of the province where the company is located (lngdp) and the company's listing years (Age). In addition, we control the industry and the year. The specific meaning of each variable is presented in Table 1.

TABLE I THE DEFINITIONS OF THE MAIN VARIABLES

\begin{tabular}{|c|c|c|}
\hline Variable & $\begin{array}{l}\text { Variable } \\
\text { Symbol }\end{array}$ & Definitions \\
\hline Corporate donation & Donation & $\begin{array}{l}\text { The proportion of total corporate } \\
\text { donations to corporate revenue. }\end{array}$ \\
\hline Control structure & Structure & $\begin{array}{l}\text { the control structure is } 1 \text { for CEO } \\
\text { when he is not a director, } 2 \text { for the } \\
\text { concurrent director and } 3 \text { for the } \\
\text { concurrent chairman. }\end{array}$ \\
\hline Ownership structure & Disp & $\begin{array}{l}\text { The ratio of the second to tenth largest } \\
\text { shareholders to the first shareholders. }\end{array}$ \\
\hline Power & Power & $\begin{array}{l}\text { The sum of control structure and } \\
\text { ownership structure after } \\
\text { standardization } 1 \text {. }\end{array}$ \\
\hline Management salary & Msalary & $\begin{array}{l}\text { The logarithm of top three Executives' } \\
\text { salaries. }\end{array}$ \\
\hline Marketization Process & Market & $\begin{array}{l}\text { Total Marketization Process Score of } \\
\text { the Provinces (Municipalities, } \\
\text { Autonomous Regions) in which the } \\
\text { Company is located. }\end{array}$ \\
\hline Cash ratio & Cash & $\begin{array}{l}\text { (Monetary Fund }+ \text { Transactional } \\
\text { Financial Assets }+ \text { Notes Receivable) } / \\
\text { Current Liabilities. }\end{array}$ \\
\hline $\begin{array}{l}\text { Proportion } \\
\text { independent directors }\end{array}$ & Indep & $\begin{array}{l}\text { Number of } \quad \text { Independent } \\
\text { Directors/Board Size. }\end{array}$ \\
\hline Growth & Growth & $\begin{array}{l}\text { (Operating income in period } t- \\
\text { operating income in period t- } \\
\text { 1)/operating income in period } t-1 .\end{array}$ \\
\hline $\begin{array}{l}\text { Logarization of GDP per } \\
\text { capita }\end{array}$ & Loggdp & $\begin{array}{l}\text { The logarithm of per capita GDP at } \\
\text { provincial level. }\end{array}$ \\
\hline Age & Age & the company's listing years \\
\hline
\end{tabular}

\section{Equations}

To test the hypothesis, we construct the following models:

Donation $=\alpha+\alpha$ power $+\alpha$ realcontrol $+\alpha$ power $\times$ realcontrol

$+\sum c v+\mu$

In the model, the coefficient a1 represents the correlation between managerial self-interest and corporate donation. If a1 is significantly positive, it means that Managerial self-interest promotes corporate donation. The coefficient a3 represents the moderating role of actual controller in the above correlation. If a3 is significantly negative, it means that the actual controller can restrain the self-interest behavior of management in corporate donation. The statistical software used in this paper is stata 15.0

\footnotetext{
${ }^{1}$ The standardized formulas are: $(\mathrm{x}-\mathrm{m}) / \mathrm{sd}, \mathrm{m}$ is the mean of variable $\mathrm{x}, \mathrm{sd}$ is the standard deviation of variable $\mathrm{x}$.
} 


\section{RESULTS}

\section{A. Descriptive Statistics}

Table 2 is sample description statistics, in which panel $\mathrm{A}$ is full sample description statistics and panel B is sub-sample description statistics. As can be seen from panel $A$, the average value of managerial power in the whole sample is 0.0355 and the median value is -0.268 . The average value of actual controller is 0.973 , which indicates that $97.3 \%$ of the enterprises in this sample have actual controllers. As can be seen from panel B, the power, donation and msalary of firms without actual controllers are significantly higher than the actual controls, which means that due to the weak supervision of shareholders, the management power is too large, and enterprises have the phenomenon of high donations and high salaries.

\section{B. Regression Results}

In order to test the hypotheses, the regression results of model are shown in Table 3. Column (1) shows the regression results of the hypothesis1. There is a significant positive correlation between managerial self-interest (power) and corporate donation $(\mathrm{a} 1=0.001, \mathrm{P}<0.01)$, indicating that managerial self-interest can improve corporate donation to a certain extent, hypothesis 1 has been verified. Column (2) shows the regression results of the hypothesis 2 . It can be seen that there is a significant negative correlation between managerial power and the interaction items (power_real) of actual controllers at the level of $5 \%(\mathrm{a} 3=-0.03, \mathrm{P}<0.05)$, which shows that the existence of actual controllers can inhibit the opportunism of executives and reduce corporate social donations. This conclusion is consistent with hypothesis 2 .

TABLE II SAMPLE DESCRIPTION

Panel A Full sample

\begin{tabular}{|c|c|c|c|c|c|c|c|c|}
\hline \multicolumn{9}{|c|}{ mple } \\
\hline variables & \multicolumn{2}{|r|}{$\mathrm{N}$} & mean & \multicolumn{2}{|c|}{$\mathrm{p} 50$} & $\mathrm{sd}$ & $\max$ & $\min$ \\
\hline donation & \multicolumn{2}{|r|}{14867} & 0.00864 & \multicolumn{2}{|c|}{0.000247} & 0.0488 & 0.420 & 0 \\
\hline power & \multicolumn{2}{|r|}{14867} & -0.0355 & \multicolumn{2}{|c|}{-0.268} & 1.370 & 3.790 & -2.530 \\
\hline realcontrol & \multicolumn{2}{|r|}{14866} & 0.973 & \multicolumn{2}{|c|}{1} & 0.163 & 1 & 0 \\
\hline msalary & \multicolumn{2}{|r|}{14867} & 14.20 & \multicolumn{2}{|c|}{14.20} & 0.735 & 17.40 & 10.40 \\
\hline cashrate & \multicolumn{2}{|r|}{14867} & 1.330 & \multicolumn{2}{|c|}{0.486} & 2.770 & 21 & 0.00332 \\
\hline indep & \multicolumn{2}{|r|}{14867} & 0.309 & \multicolumn{2}{|c|}{0.333} & 0.138 & 0.571 & 0.0300 \\
\hline market & \multicolumn{2}{|r|}{14867} & 14.40 & \multicolumn{2}{|c|}{14.40} & 0.593 & 15.80 & 12.80 \\
\hline growth & \multicolumn{2}{|r|}{14867} & 0.174 & \multicolumn{2}{|c|}{0.126} & 0.325 & 1.710 & -0.550 \\
\hline $\operatorname{lngdp}$ & \multicolumn{2}{|r|}{14867} & 10.90 & \multicolumn{2}{|c|}{11} & 0.490 & 11.80 & 9.610 \\
\hline \multirow[t]{2}{*}{ age } & \multicolumn{2}{|r|}{14867} & 12.90 & \multicolumn{2}{|c|}{13} & 6.730 & 27 & 0 \\
\hline & \multicolumn{6}{|c|}{ Panel B Sub-sample } & & \\
\hline \multirow{2}{*}{ variables } & \multicolumn{3}{|c|}{ Group of Actual Controllers } & \multicolumn{3}{|c|}{ Group of Non-actual Controllers } & \multicolumn{2}{|c|}{ Difference2 } \\
\hline & $\mathrm{N}$ & mean & $\mathrm{p} 50$ & $\mathrm{~N}$ & mean & $\mathrm{p} 50$ & Mean & $\mathrm{p} 50$ \\
\hline donation & 14458 & 0.008 & 0.0002 & 408 & 0.0175 & 0.000387 & $-0.009 * * *$ & $-0.0002 * * *$ \\
\hline power & 14458 & -0.068 & -0.294 & 408 & 1.13 & 1.15 & $-1.196^{* * *}$ & $-1.444 * * *$ \\
\hline msalary & 14458 & 14.2 & 14.2 & 408 & 14.9 & 14.8 & $-0.696 * * *$ & $-0.6^{* * * *}$ \\
\hline cashrate & 14458 & 1.33 & 0.488 & 408 & 1.27 & 0.453 & 0.06 & 0.035 \\
\hline indep & 14458 & 0.31 & 0.333 & 408 & 0.289 & 0.333 & $0.021 * * *$ & 0.000 \\
\hline market & 14458 & 14.4 & 14.4 & 408 & 14.4 & 14.4 & 0.037 & 0.000 \\
\hline growth & 14458 & 0.174 & 0.126 & 408 & 0.177 & 0.122 & 0.003 & 0.004 \\
\hline lngdp & 14458 & 10.9 & 11 & 408 & 11 & 11.1 & $-0.120 * * *$ & $-0.1 * * *$ \\
\hline age & 14458 & 12.8 & 13 & 408 & 14.1 & 13 & $-1.316^{* * *}$ & $-0.000 * * *$ \\
\hline
\end{tabular}

${ }^{2}$ T-statistics test was used for mean test, Wilcoxon test was used for median test ,and $* * *, * * *$ and $*$ showed significant levels of $1 \%, 5 \%$ and $10 \%$, respectively. 
TABLE III REGRESSION RESULTS ${ }^{3}$

\begin{tabular}{|c|c|c|}
\hline variables & $\begin{array}{l}(1) \\
\text { donation }\end{array}$ & $\begin{array}{l}(2) \\
\text { donation }\end{array}$ \\
\hline \multirow[t]{2}{*}{ power } & $0.001 * * *$ & $0.004 * * *$ \\
\hline & (3.99) & $(3.15)$ \\
\hline \multirow[t]{2}{*}{ realcontrol } & & 0.002 \\
\hline & & $(0.84)$ \\
\hline \multirow[t]{2}{*}{ power_real } & & $-0.003 * *$ \\
\hline & & $(-2.19)$ \\
\hline \multirow[t]{2}{*}{ msalary } & $0.002 * * *$ & $0.002 * * *$ \\
\hline & $(3.48)$ & $(3.75)$ \\
\hline \multirow[t]{2}{*}{ cashrate } & $0.001 * * *$ & $0.001 * * *$ \\
\hline & (5.38) & $(8.85)$ \\
\hline \multirow[t]{2}{*}{ indep } & 0.003 & 0.003 \\
\hline & $(0.70)$ & $(0.86)$ \\
\hline \multirow[t]{2}{*}{ market } & 0.001 & 0.001 \\
\hline & $(1.45)$ & $(1.46)$ \\
\hline \multirow[t]{2}{*}{ growth } & -0.001 & -0.001 \\
\hline & $(-0.48)$ & $(-0.57)$ \\
\hline \multirow[t]{2}{*}{ lngdp } & $-0.006 * * *$ & $-0.006^{* * *}$ \\
\hline & $(-4.91)$ & $(-4.82)$ \\
\hline \multirow[t]{2}{*}{ age } & $0.001 * * *$ & $0.001 * * *$ \\
\hline & $(12.65)$ & $(16.68)$ \\
\hline year and industry & yes & yes \\
\hline \multirow[t]{2}{*}{ Constant } & -0.011 & -0.014 \\
\hline & $(-0.87)$ & $(-1.06)$ \\
\hline Observations & 14,867 & 14,866 \\
\hline R-squared & 0.07 & 0.07 \\
\hline
\end{tabular}

\section{ROBUSTNESS TEST}

In order to make the previous research conclusions robust, this paper makes the following adjustments: Firstly, considering the scale and impact of the large earthquake, which will seriously affect the level of corporate donations, we excluded the research samples of Wenchuan earthquake, Yushu earthquake and Ya'an earthquake in 2008, 2010 and 2013 in order to eliminate this interference, then re-exam to the above assumptions. Secondly, like Jun [18], this paper regains Tobin $\mathrm{Q}$ as the agent variable of enterprise growth. Combined with the above regression results, there is no significant change in the empirical analysis, which shows that the above conclusions are robust.

\section{CONCLUSIONS}

There are many motives for corporate donation, which can be divided into enterprise level and management level. At the enterprise level, donation motivation includes strategic motivation, political motivation, management utility motivation and altruistic motivation; through donation managers may seek rent for self-interest motivation, the existence of actual controllers can reduce the enterprise donation induced by management self-interest behavior Therefore, in the process of market-oriented reform, while promoting corporate donation, we should improve corporate governance and steadily promote the healthy and orderly development of social donation in China.

\section{REFERENCES}

[1] R. Zhang, Z. Rezaee, J. Zhu, "Corporate Philanthropic Disaster Response and Ownership Type: Evidence from Chinese Firms' Response to the Sichuan Earthquake," Journal of Business Ethics, 2010, vol.91, pp.51-63.

[2] Z. Hongwu, "Comprehensive Analysis of the Role of Enterprise Donation," China's Industrial Economy.2007,vol.2,pp.77-85.(In Chinese)

[3] L. Sihai, C. Xuan, S. Xianzhong, "The Generosity of the Poor: A Study of Strategic Motivation,” Managing the World. 2016 ,vol5, pp.116-127. (In Chinese)

[4] D. Yiyi, P. Yue, and F. Shu, "Are philanthropic donations from Chinese enterprises a kind of "political donation"? - Evidence from the replacement of the Secretary of the Municipal Party Committee," Economic Research, 2014, vol2, pp. 74-86. (In Chinese)

[5] L. Sihai, L. Qirui and S. Xianzhong, "Behind the generous donations of loss-making enterprises," China's industrial economy, 2012 ,vol8 pp.148-160. (In Chinese)

[6] S. Liwei, G.li and Z. Tao, "Corporate Donation and Economic Motivation: An Empirical Study on Donation of Listed Companies in China after Wenchuan Earthquake," Economic Research, 2008,vol11, pp.51-61. (In Chinese)

[7] P. Yue, W. Ruoyu and L. Siyi, " Private Good Will: New Evidence Based on Corporate Charitable Donation Behavior in Typhoon," Industrial Economy of China, 2017 ,vol05,pp. 133-151. (In Chinese)

[8] W.O. Brown, E. Helland, and J.K. Smith, “Corporate philanthropic practices,"Journal of Corporate Finance, 2006, vol12, pp. 855-877.

[9] M.C. Jensen, W. H Meckling, "Theory of the Firm: Managerial Behavior, Agency Costs and Ownership Structure”. Social Science Electronic Publishing, 1976,vol 3,pp.305-360.

[10] D. H. Saiia,, D. Cyphert, "The Public Discourse of the Corporate Citizen," Corporate Reputation Review. 2003, 6,47-57.

[11] D. Ma,; W. Paris, “Tocquevillian Moments: Charitable Contributions by Chinese Private Entrepreneurs,” Social Forces. 2006, vol85,pp. 943 964

[12] S.Arendt, M. Brettel, "Understanding the influence of corporate social responsibility on corporate identity, image, and firm performance," Management Decision. ,2012, vol48,pp.1469-1492

[13] L. Jian, C. Shuangying and G. Qingen, "Political Participation, Governance Structure and Charitable Donation of Private Enterprises,' Managing the World, 2010 ,vol07,pp. 109-118. (In Chinese)

[14] H. Wang, C. Qian, "Corporate Philanthropy and Corporate Financial Performance :The Roles of Stakeholder Response and Political Access," Academy of Management Journal. 2011, vol54, pp.1159-1181.

[15] C. A. Hemingway, P. W. Maclagan, "Managers' Personal Values as Drivers of Corporate Social Responsibility". Journal of Business Ethics, 2004, vol50,pp.33-44

[16] J.D. Werbel,, S.M. Carter, "The CEO's Influence on Corporate Foundation Giving," Journal of Business Ethics, 2002, vol40,pp.47-60.

[17] T. Justin, Y. Tang, "Donate Money, but Whose? An Empirical Study of Ultimate Control Rights, Agency Problems, and Corporate Philanthropy in China.," Journal of Business Ethics ,2016,vol134,pp.593-610.

[18] B. Jun, L. Lishuai, "Traceability of Overinvestment in State-owned Enterprises: Government Intervention or Management Self-interest?' Accounting Research, 2014 ,vol02, pp.41-48+95. (In Chinese)

${ }^{3}$ Robust t-statistics in parentheses, ${ }^{*} \mathrm{p}<0.1,{ }^{*} \mathrm{p}<0.05, * * * \mathrm{p}<0.01$ (two-tailed). 